\title{
ANTARA PEMERATAAN DAN EKSPLOITASI LAHAN: SIDOARJO DALAM SWP GERBANGKERTOSUSILA, 1996-2011
}

\author{
BETWEEN EQUALIZATION AND LAND EXPLOITATION: \\ SIDOARJO IN THE SWP GERBANGKERTOSUSILA, \\ 1996-2011
}

\author{
Ronal Ridho'i \\ Jurusan Sejarah Fakultas Ilmu Sosial Universitas Negeri Malang \\ Jln. Semarang No.5, Kota Malang \\ ronal.ridhoi.fis@um.ac.id
}

Diterima tanggal 6 September 2018

Disetujui tanggal 27 Desember 2018

\begin{abstract}
The main goal of land use changes is a good development and equalization. That goal is trying to be achieved in a program of development areas called SWP Gerbangkertosusila in East Java. This program desires to develop surrounding areas of Surabaya Metropolitan City. In fact, this program is not fulfilled its goal yet and make many problems to the impacted surrounding areas such as Sidoarjo. This paper is aimed to describe the change of land use and industrial impact in Sidoarjo caused by program implementation of SWP Gerbangkertosusila. Take case study of SWP Gerbangkertosusila and uses the historical method (peruses an archives, newspaper, books, and other literatures), this paper proves that SWP Gerbangkertosusila, indeed, was not equalizing surrounding areas of Surabaya. This paper showed that the program looks like an exploitation of land around Surabaya Metropolitan City as a center of development in East Java. Based on this paper, stakeholders should be focuses of land used planning around Sidoarjo in the future.
\end{abstract}

Keywords: equalization, land exploitation, Gerbangkertosusila, and Sidoarjo.

\begin{abstract}
ABSTRAK
Salah satu tujuan ideal dari perubahan tata guna lahan adalah pembangunan dan pemerataan wilayah. Tujuan tersebut diupayakan dalam program Satuan Wilayah Pengembangan (SWP) Gerbangkertosusila di Jawa Timur. Program tersebut seharusnya dapat mengembangkan wilayah-wilayah di sekitar Kota Metropolitan Surabaya. Kenyataannya, program ini belum mencapai tujuan dan banyak menimbulkan permasalahan bagi daerah terdampak program, salah satunya Sidoarjo. Tulisan ini dimaksud untuk mengkaji perubahan penggunaan lahan dan dampak industrialisasi di Sidoarjo akibat implementasi
\end{abstract}


program SWP Gerbangkertosusila. Dengan mengambil studi kasus SWP Gerbangkertosusila dan menggunakan metode penelitian sejarah (melalui pembacaan arsip, surat kabar, dan berbagai literatur), tulisan ini membuktikan bahwa SWP Gerbangkertosusila memang tidak memeratakan daerah sekitar Surabaya. Tulisan ini menunjukkan bahwa program tersebut malah membuka eksploitasi lahan di sekitar Kota Metropolitan Surabaya sebagai pusat perkembangan di Jawa Timur. Berdasarkan tulisan ini, pemangku kebijakan diharapkan mampu lebih menitikberatkan perencanaan penggunaan lahan bagi pembangunan wilayah Sidoarjo dan sekitarnya di masa yang akan datang.

Kata kunci: pemerataan, eksploitasi, Gerbangkertosusila, dan Sidoarjo.

\section{A. PENDAHULUAN}

Salah satu hal penting yang dilihat dari suatu kawasan adalah peran dan fungsi dari kawasan tersebut. Peran kawasan dapat dilihat dari sumbangan yang diberikan kepada pemerintah dan masyarakat sekitar apa yang dihasilkannya. Fungsi dapat dilihat dari penggunaan kawasan tersebut sebagai pusat kegiatan tertentu. Menurut pendapat Yunus (2014: 6), di abad ke21 ini kebanyakan kota atau kawasan tertentu mempunyai fungsi jamak. Hal ini disebabkan karena kegiatan manusia sudah beragam, seperti kegiatan politik, ekonomi, sosial, dan budaya yang berpusat dalam suatu kawasan tertentu.

Fungsi yang beragam tersebut membuat pemerintah memunculkan kebijakan-kebijakan baru, khususnya untuk mengatur peran dan fungsi kota. Kebijakan demi kebijakan baru mengena pada salah satu kawasan kota kabupaten yang setidaknya sejak masa kolonial telah berperan penting sebagai hinterland dari Kota Surabaya, yakni Sidoarjo.

Beberapa laporan pemerintah kolonial menyatakan bahwa pengguna- an lahan untuk perindustrian (khususnya industri gula) di Sidoarjo sudah dilakukan sejak paruh pertama abad ke-19, tepatnya pada tahun 1835 (Basundoro, 2012: 244). Pada masa itu, penggunaan lahan difokuskan pada industri gula karena merupakan komoditas ekspor yang punya nilai jual tinggi. Sejak itu, pemerintah Hindia Belanda menjadikan daerah ini sebagai kota industri perkebunan.

Pada pertengahan abad ke-19, Sidoarjo (yang dikenal dengan nama Sidokare) berperan sebagai hinterland yang menghasilkan ekspor berupa tebu dan beras. Hal ini disebabkan oleh letak geografis Sidoarjo yang berada di Delta Sungai Brantas. Dengan demikian kawasan tersebut tumbuh subur dan menyediakan air yang melimpah. Kawasan delta sungai yang bermuara di Selat Madura tersebut sangat cocok digunakan untuk pertanian, perkebunan, dan pertambakan (Tjiptoatmodjo, 1983: 96-97). Pada perkembangan selanjutnya, penggunaan lahan difokuskan pada industri bahan mentah dan industri manufaktur yang sudah berjalan sampai akhir abad ke20. 
Pada akhir abad ke-20, pemerintah provinsi dan pemerintah daerah menjadikan Sidoarjo sebagai kota industri. Hal itu erat kaitannya dengan rencana Gerbangkertosusila yang dicanangkan oleh Gubernur Jawa Timur. Dalam rencana tersebut, Sidoarjo diproyeksikan sebagai kawasan penyangga bagi Kota Metropolitan Surabaya. Hal ini diperkuat oleh disertasi Adika (2003) "Perkembangan Wilayah Pinggiran Kota Metropolitan Surabaya dan Mobilitas Tenaga Kerja (Kasus Kabupaten Sidoarjo)". Adika membahas fenomena tersebut dari perspektif perencanaan wilayah dan kota, khususnya pemekaran wilayah. Adika memperkirakan pusat Kota Metropolitan Surabaya pada akhir abad ke-20 sudah tidak mungkin lagi mengakomodasi pembangunan industri karena keterbatasan lahan. Keterbatasan tersebut berlanjut pada pelimpahan fungsi sebagai kota industri ke Sidoarjo.

Tidak hanya itu, Sidoarjo yang merupakan bagian dari Jawa Timur juga dibahas dalam buku Balanced Development: East Java in the New Order (Dick, eds., 1997). Buku ini menguraikan pembangunan sosialekonomi di Jawa Timur pada masa Orde Baru. Dalam periode tersebut, pembangunan di Jawa Timur dicirikan sebagai gabungan yang kompleks antara dinamika, disiplin, dan keberagaman. Gabungan sifat-sifat tersebut telah membawa pada pertumbuhan ekonomi berkelanjutan dalam konteks pembangunan berimbang. Misalnya, pembangunan industri di Surabaya sebagai kota metropolitan di Jawa Timur memang tidak secepat Jakarta. Justru hal ini yang baik, karena Surabaya tidak mendominasi wilayah lainnya di Jawa Timur sehingga dapat mendukung pembangunan yang berimbang. Berbeda dengan Jakarta yang mendominasi wilayah sekitarnya, khususnya Jawa Barat. Apakah pendapat tersebut masih bisa dipertahankan, mengingat kebijakan Gerbangkertosusila lebih cenderung melakukan pemanfaatan lahan di daerah sekitar pusat perkembangan.

Untuk menelaah perubahan penggunaan lahan di Sidoarjo, penulis menggunakan beberapa kategori kajian tentang wilayah urban dan lingkungan yang diajukan Richard T.T. Forman (2008) dalam bukunya Urban Regions: Ecology and Planning Beyond the City. Pertama, kajian mengenai lahan (tanah, pertamanan, perkebunan), kota berkelanjutan (pembangunan berkelanjutan), dan bencana alam. Kedua, kajian mengenai perubahan iklim, kepunahan spesies, dan kelangkaan air yang merupakan tantangan besar bagi ekologi di kotakota besar. Ketiga, ide-ide, peraturan dan kebijakan pemerintah dalam upaya untuk mengelola lingkungan kota.

Penulis juga mempelajari konsep pemekaran wilayah yang diajukan Chris Chouch, dkk. (2007) dalam Urban Sprawl In Europe: Landscapes, LandUse Change \& Policy. Chouch melakukan studi perbandingan terhadap 
Handep, Vol. 2, No. 1, Desember 2018

fenomena pemekaran yang terjadi di kota-kota Eropa. Selain itu, tipe pemekaran wilayah di Eropa juga dijelaskan dalam buku ini. Bagian yang terpenting yaitu tentang model dan kebijakan pemerintah tentang pemekaran wilayah yang pada akhirnya akan membawa pada pembangunan kota berkelanjutan. Kajian ini dapat dijadikan pembanding pada kasus di Sidoarjo karena pada dasarnya mempunyai kesamaan pola dalam hal pemekaran wilayah Kota Metropolitan Surabaya.

Untuk menelaah masalah kebijakan pemerintah terhadap kawasan perkotaan, buku Freire dan Stren (2001) The Challenge of Urban Government: Policies and Practice perlu untuk dibaca. Buku ini relevan untuk kajian penulis karena berisi tentang permasalahan perkotaan dan tantangan pemerintah dalam membuat kebijakan, khususnya kebijakan terhadap kota metropolitan. Buku ini juga berisi berbagai upaya pemerintah untuk memajukan perekonomian kota dengan kebijakan dan pengelolaan yang terstruktur dan telah direncanakan. Masalah penggunaan lahan dan pengelolaan lingkungan juga dibahas dalam buku ini. Penjelasan utama buku yang menjadi acuan penelaahan dalam tulisan ini adalah bagaimana kebijakan pemerintah urban menangani permasalahan di perkotaan.

Pelimpahan fungsi kota industri mendasari tujuan penulisan artikel ini. Penulis memfokuskan temporal terkait perubahan penggunaan lahan di
Sidoarjo sejak tahun 1996-2011. Alasan penulis mengambil temporal tersebut karena tahun 1996 mulai ada kebijakan Satuan Wilayah Pengembangan (SWP) Gerbangkertosusila. Tahun 2011 dipilih sebagai batas akhir penulisan karena pada tahun tersebut muncul kebijakan baru tentang penambahan SWP, yang kemudian disebut dengan Gerbangkertosusila Plus. Disadari atau tidak, Gerbangkertosusila telah mengubah kondisi lingkungan. Industrialisasi dan urban sprawl (pemekaran wilayah) yang menjadi tujuan utama dari kebijakan ini dapat diasumsikan sebagai pengeksploitasian lahan secara terstruktur.

Artikel ini menggunakan metode sejarah yang terdiri atas empat tahapan, yaitu: heuristik, kritik, interpretasi dan historiografi (Kuntowijoyo, 2003). Tahap awal meliputi pengumpulan sumber primer (seperti: arsip pemerintahan, koran, dan laporan tahunan) dan sumber sekunder (berupa buku teks, artikel dalam jurnal, tesis, dan disertasi). Sumber-sumber tersebut diperoleh dari Arsip Nasional Republik Indonesia, Arsip Provinsi Jawa Timur, Perpustakaan UGM, Perpustakaan Daerah Jawa Timur, Badan Perencanaan Pembangunan Daerah (Bappeda) Sidoarjo, Balai Lingkungan Hidup Kabupaten Sidoarjo, Badan Pusat Statistik (BPS), dan Pusat Informasi Kompas. Selain itu, penulis juga mengunjungi beberapa website yang menyimpan sumber tentang Sidoarjo. Setelah mendapatkan sumber yang relevan dengan tema penelitian, 
penulis kemudian mengkritik dan menginterpretasikannya. Kerja kritik dan interpretasi terutama dilakukan terhadap sumber surat kabar masa Orde Baru yang sarat dengan muatan politik dalam setiap pemberitaan terkait industrialisasi di Sidoarjo. Pemberitaan yang cenderung memuat sudut pandang penguasa dan kaum industrialis harus dibandingkan dengan sumbersumber pembanding ini. Terakhir, penulis menuliskannya dalam bentuk historiografi yang diakronis.

Berdasarkan latar belakang yang telah dipaparkan di atas, penulis ingin mengetahui proses transformasi lahan di Sidoarjo akibat industrialisasi dan kebijakan SWP Gerbangkertosusila. Selain itu, penulis juga memaparkan kondisi lingkungan Sidoarjo yang sudah semakin memburuk akibat industrialisasi yang semakin masif.

\section{B. HASIL DAN BAHASAN}

\section{Awal Mula Penggunaan Lahan Industri di Sidoarjo}

Laporan pemerintah kolonial menyebutkan bahwa penggunaan lahan untuk perindustrian (khususnya industri gula) di Sidoarjo sudah dilakukan sejak paruh pertama abad ke19 , tepatnya pada tahun 1835 . Hal ini ditandai pembangunan pabrik gula di Balongbendo, Sidoarjo bagian barat. Setelah itu, perkembangan industri gula semakin pesat. Bahkan, hingga tahun 1910 terdapat 14 pabrik gula yang beroperasi di Kabupaten Sidoarjo (Arsip Karesidenan Surabaya atau ANR, No.560). Hal ini wajar karena hingga paruh kedua abad ke-19 Sidoarjo masih menjadi bagian dari Afdeeling/Kabupaten Surabaya yang merupakan daerah dengan basis ekonomi perkebunan di Jawa bagian timur (lihat gambar 1).

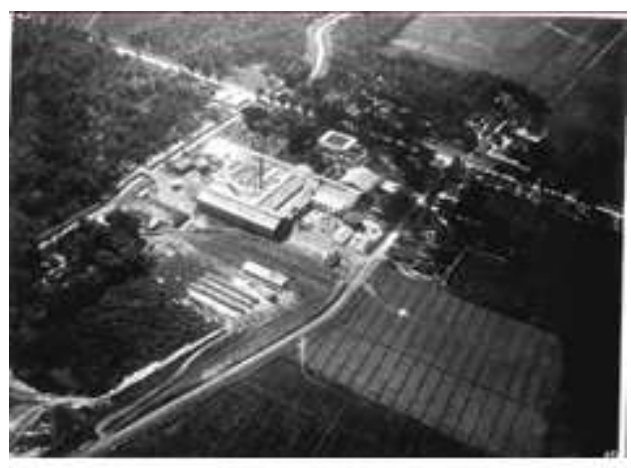

Gambar 1. Foto udara Pabrik Gula Buduran, Sidoarjo 1920.

Sumber: colonialarchitecture.eu, diakses pada Juli 2018.

Pada abad ke-20, mulai banyak industri non-perkebunan yang berkembang. Adika (2003) menyebutkan bahwa sudah ada industri kerajinan berupa tas yang telah dirintis sejak tahun 1913. Industri kerajinan tas tersebut saat ini berkembang menjadi kerajinan tas dan koper, bahkan sudah mencakup barang-barang aksesoris seperti dompet, sabuk, jaket, dan sepatu yang berbahan dasar kulit. Selain itu, karena hasil tambak udang yang melimpah, kawasan ini juga mendirikan industri krupuk udang dan petis yang juga masih tetap eksis sampai saat ini. Bahkan, penelitian Dick (2002: 295-296) memaparkan bahwa sekitar tahun 1950-an Sidoarjo telah mengembangkan industri kerajinan batik dan kerajinan yang berhubungan dengan tekstil. 
Handep, Vol. 2, No. 1, Desember 2018

Hal itu menjadi wajar karena di awal tahun 1950-an pemerintah pusat mulai membangun industri-industri strategis, salah satunya yaitu industri tekstil. Sidoarjo sebagai salah satu sasaran proyek industri strategis tersebut juga mempunyai pabrik tekstil besar di Balongbendo, yaitu PT Ratatex (Ridho'i, 2017a: 206). Belum diketahui secara pasti mengapa industri tekstil tersebut berlokasi di Sidoarjo, padahal di daerah ini tidak ada sumberdaya alam penghasil bahan baku untuk pembuatan tekstil. Hal ini tentu berbeda dengan Gresik yang saat itu lebih dikembangkan industri semen karena berada di kawasan yang berkapur dan dekat dengan Pantai Utara Jawa (lihat gambar 2).

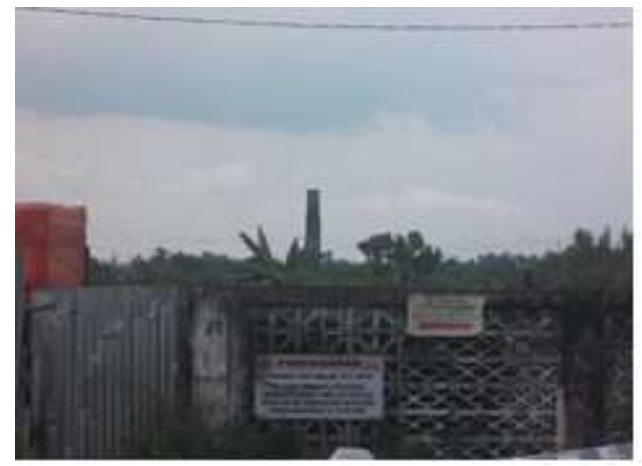

Gambar 2. Foto cerobong pabrik tekstil PT Ratatex - bekas Pabrik Gula Balongbendo saat ini. Sumber: dokumentasi penulis.

Perkembangan industrialisasi setelah tahun 1950-an menjadi semakin pesat. Terutama pada masa Orde Baru sampai awal abad ke-21. Periode tersebut menandai pendirian industri manufaktur skala besar di Sidoarjo. Perubahan penggunaan lahan pun terjadi, dari sawah ke pabrik, dari sawah ke permukiman, dan dari sawah ke berbagai jenis pertokoan. Lahan subur di Sidoarjo yang cocok untuk pertanian dan perkebunan tebu mulai berkurang. Data BPS menunjukkan berkurangnya area persawahan di Sidoarjo dari 26.334 ha tahun 2002 menjadi 22.342 ha tahun 2011 (BPS, 2003; 2012: 207).

Pada masa Orde Baru investor asing mulai berdatangan ke Sidoarjo. Mereka menanamkan modalnya untuk mendirikan industri manufaktur dan industri kimia. Kebanyakan investor tersebut bergerak di bidang industri multi-nasional, seperti pabrik sepatu Echo, pabrik baja, pabrik kulit, PT Ferro Sidoarjo dan sebagainya. Sampai tahun 2000, industri manufaktur di Sidoarjo masih mendominasi kawasan lain yang termasuk Gerbangkertosusila (Laporan Dinas Penanaman Modal Jatim, 2001). Hal ini membuktikan bahwa Sidoarjo memiliki peran penting dalam hal industrialisasi. Penggunaan lahan industri semakin bertambah sejak dicanangkan SWP Gerbangkertosusila.

Sementara itu, Kota Surabaya di awal abad ke-21 mengalami permasalahan besar, yakni keterbatasan lahan. Wilayah dalam kota sudah tidak memungkinkan pembangunan industri, kantor pemerintahan, maupun fasilitas umum. Melihat perkembangan industri manufaktur yang semakin pesat, Pemerintah Provinsi Jawa Timur mengalihfungsikan Sidoarjo sebagai kawasan industri demi menunjang pertumbuhan industri di Kota Surabaya. Ini dilakukan dengan harapan dapat mengatasi permasalahan lahan di Surabaya. 
Penggunaan lahan untuk industri tidak hanya di Sidoarjo. Kota Gresik juga menjadi sasaran pengembangan wilayah tersebut. Sebagai kota industri, Gresik berperan penting dalam hal industri berat. Salah satu industri terbesar yang sudah ada sejak tahun 1953 adalah Semen Gresik. Pada awal abad ke-21 kota ini mempunyai kadar polutan yang tinggi akibat industrialisasi tersebut (Basundoro, 2001: 137). Bagaimanakah dengan Sidoarjo? Mengapa kota ini juga dijadikan sebagai kota industri?

Faktor utama yang menentukan perkembangan industri dan pertumbuhan wilayah adalah masalah lahan. Secara geografis, Sidoarjo dan Gresik merupakan daerah pinggiran yang berbatasan langsung dengan Kota Surabaya (lihat gambar 3). Kawasan ini sebenarnya lebih cocok untuk industri minyak dan gas. Tapi, karena lokasinya dekat dengan Kota Surabaya maka kawasan ini dikembangkan menjadi berbagai macam industri.

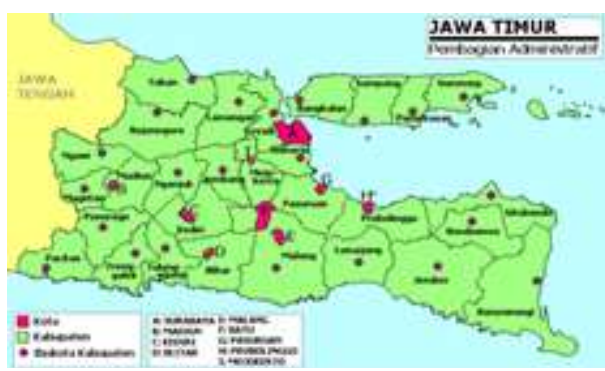

Gambar 3. Peta Jawa Timur dan daerah di sekitarnya.

Sumber:https://upload.wikimedia.org/ wikipedia/commons/1/19/

East_Java_province.png, diakses pada Desember 2018.

Selain itu, syarat industri harus ada sumber air yang melimpah. Sidoarjo merupakan kawasan yang strategis karena berada di percabangan Sungai Brantas dan Gresik berada dekat dengan aliran Sungai Bengawan Solo. Oleh karena itu, kawasan ini cocok untuk industri dan pemerintah provinsi memasukkan kedua kota tersebut ke dalam SWP Gerbangkertosusila.

\section{Gerbangkertosusila:Kapitalisme Peri-urban}

Gerbangkertosusila merupakan Satuan Wilayah Pengembangan (SWP) terbesar di Jawa Timur. Kawasan ini terdiri atas 7 kota/kabupaten dengan Surabaya sebagai pusat perkembangannya. Ketujuh kota/kabupaten tersebut yaitu Kabupaten Gresik, Kabupaten Bangkalan, Kabupaten Mojokerto, Kota Mojokerto, Kota Surabaya, Kabupaten Sidoarjo, dan Kabupaten Lamongan (lihat gambar 4). Satuan wilayah tersebut dapat diidentikkan seperti Jabodetabek di Jawa Barat dengan Kota Jakarta sebagai pusatnya Peraturan Daerah (Perda) Jatim No.4/1996 tentang Rencana Tata Ruang Wilayah (RTRW) Provinsi Jawa Timur.

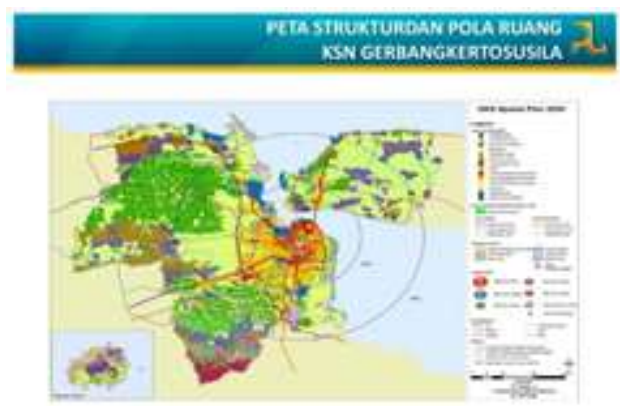

Gambar 4. Peta struktur dan pola ruang SWP Gerbangkertosusila.

Sumber: Sekretariat Jenderal Kementerian Pekerjaan Umum, 2013. 
Handep, Vol. 2, No. 1, Desember 2018

Wilayah Gerbangkertosusila merupakan kawasan andalan di Jawa Timur. Wilayah ini mengalami pertumbuhan ekonomi yang cukup pesat dan menjadi kawasan strategis nasional. Hingga tahun 2011 Pendapatan Asli Daerah (PAD) Sidoarjo masih didominasi sektor industri manufaktur, yaitu mencapai 27,5 triliun. Sementara sektor pertanian dan perkebunan hanya menyumbangkan 1,7 triliun (BPS, 2012: 330). Perbedaan pertumbuhan ekonomi di wilayah ini terjadi sejalan dengan fungsi dan perannya sebagai pusat pertumbuhan wilayah di Jawa Timur, bahkan pengaruhnya hingga wilayah Indonesia Timur (Santoso, 2010: 2).

Pertumbuhan ekonomi di kawasan Gerbangkertosusila secara tidak langsung menambah pendapatan dan memajukan bidang perekonomian di Kota Surabaya. Namun, hal itu tidak terlepas dari dukungan kotakota satelitnya. Sidoarjo merupakan salah satu kota satelit yang difungsikan sebagai kawasan industri, permukiman, dan juga pertokoan. Adika (2003) menjelaskan bahwa Sidoarjo merupakan wilayah kesempatan bagi para pekerja yang ingin bekerja di Kota Surabaya. Ketika mereka sudah tidak bisa lagi bekerja di Surabaya karena jumlah pabrik yang semakin berkurang, mereka lebih memilih bekerja di Sidoarjo, Gresik, dan Mojokerto.

Kondisi ini merupakan praktik kapitalisme yang terjadi di kawasan peri-urban. Seperti pendapat Wood
(2002) bahwa dalam masyarakat kapitalisme semuanya merupakan komoditas pasar, baik buruh, tanah, maupun modal. Hal ini serupa dengan kondisi yang terjadi di Sidoarjo, di mana tanah, pekerja, dan modal sudah menjadi komoditas. Wilayah peri-urban sudah mengalami urbanisasi secara pesat akibat kebijakan Gerbangkertosusila tersebut. Orang sudah tidak lagi berdatangan untuk mencari kerja di Surabaya. Tujuan mereka sudah beralih ke Sidoarjo karena menurut mereka kawasan ini menyediakan banyak lapangan pekerjaan bagi golongan menengah ke bawah, seperti buruh pabrik dan pekerjaan lain dalam bidang jasa. Hal ini dibuktikan daya serap tenaga kerja industri besar dan menengah di Sidoarjo mencapai 150.499 orang hingga tahun 2010 (BPS, 2012: 230).

Selain incaran lokasi kerja, Sidoarjo juga menjadi lokasi tempat tinggal alternatif bagi para pekerja di Surabaya. Mereka yang tidak mampu menjangkau harga tanah di Surabaya yang sudah sangat mahal, kebanyakan membeli tanah atau rumah di Sidoarjo.

Penempatan Sidoarjo sebagai lokasi kerja dan bermukim memulai proses urbanisasi ditandai oleh pertambahan penduduk. Berdasarkan sensus penduduk tahun 1990, 2000, dan 2010 diketahui bahwa jumlah penduduk di Kabupaten Sidoarjo terus mengalami peningkatan. Jumlah penduduk Sidoarjo mencapai 1.167.467 orang pada tahun 1990 dan bertambah menjadi 1.945 .252 orang pada tahun 
2010 (BPS, 2012: 83). Mereka kebanyakan para pendatang dari luar kota dan luar Pulau Jawa. Penduduk Sidoarjo tetap menjadi penduduk terbanyak kedua di Jawa Timur setelah Kota Surabaya (Adika, 2003: 162).

Ini semakin mempercepat proses kapitalisme peri-urban. Dengan datangnya pekerja dari luar kota dan luar pulau maka pertumbuhan kapitalisme semakin pesat. Banyak investor bermunculan, para buruh yang mencari pekerjaan, dan tanahtanah persawahan yang dijual untuk dijadikan industri. Sidoarjo yang dahulu didominasi pedesaan dengan lahan pertanian, perkebunan dan pertambakannya kini berkembang ke arah perkotaaan.

\section{Pemerataan Atau Eksploitasi Wilayah?}

Sejak abad ke-19, kawasan Sidoarjo menjadi pusat eksploitasi lahan. Bedanya, dulu eksploitasi dipusatkan pada industri perkebunan maka di akhir abad ke-20 beralih ke industri manufaktur dan permukiman. Pemerintah Provinsi Jawa Timur dan Kabupaten Sidoarjo melakukan hal ini untuk menjawab keterbatasan lahan yang terjadi di Kota Metropolitan Surabaya. Pemerintah mengeluarkan kebijakan yang secara tidak langsung merupakan ajang eksploitasi lahan di sekitar kota metropolitan. Hal ini tidak disadari oleh penduduk karena mereka menganggap kebijakan tersebut menguntungkan bagi mereka.
Berkembangnya Kota Surabaya sebagai kota pusat ekonomi bisnis memberikan dampak langsung bagi daerah peri-urbannya. Surabaya memberikan kesempatan besar bagi para pekerja yang mayoritas pendatang untuk bekerja di sektor bisnis. Akibatnya, penyediaan perumahan dirasa perlu ditambah lagi. Mengingat kondisi lahan yang sudah sangat terbatas, maka pilihan utama para pekerja tersebut adalah membuat rumah atau membeli rumah di Sidoarjo. Kabupaten Sidoarjo berjarak relatif dekat dengan Kota Surabaya sehingga lebih diminati masyarakat sebagai alternatif daerah hunian.

Pada tahun 2004, REI (Real Estate Indonesia) melaporkan bahwa penggunaan lahan untuk perumahan dan permukiman di Sidoarjo mencapai 400-1.200 rumah per bulan. Dari data tersebut, sebanyak 80\% merupakan perumahan kelas menengah ke bawah. Sisanya, merupakan perumahan mewah, ruko, dan rumah kantor (Kompas, 1 September 2004). Dapat dikatakan bahwa kebanyakan pekerja di Surabaya dan Sidoarjo masih berada dalam kondisi ekonomi menengah ke bawah. Mereka lebih memilih tinggal di Sidoarjo daripada di Kota Surabaya yang semakin mahal biaya hidupnya.

P e mbentukan S a t u an Wilayah Pembangunan (SWP) Gerbangkertosusila menurut Perda Provinsi Jawa Timur No.4/1996 tentang RTRW dan PP No.47/1996 tentang RTRW Nasional, bertujuan untuk mewujudkan pemerataan pembangunan 
Handep, Vol. 2, No. 1, Desember 2018

antardaerah. Namun, pada kenyataannya hingga tahun 2009 kesenjangan antarkabupaten dan Kota (peri-urban) di wilayah Gerbangkertosusila tersebut masih terus terjadi. Kesenjangan wilayah di Gerbangkertosusila menurut Handayani (2009) dapat ditinjau menurut tiga dimensi pembangunan, yaitu pembangunan ekonomi, sosial dan lingkungan. Pembangunan yang dilakukan di Gerbangkertosusila selama ini ternyata berdampak pada peningkatan kesenjangan antarkabupaten dan kota di wilayah tersebut. Kesenjangan terutama terjadi antara Kota Surabaya dengan wilayah peri-urbannya (Kabupaten Gresik dan Sidoarjo) dengan wilayah-wilayah belakangnya, yaitu Kabupaten Mojokerto, Lamongan, dan Bangkalan.

Selain itu, pembangunan di Gerbangkertosusila juga berkontribusi terhadap peningkatan kemiskinan, pengangguran, dan degradasi lingkungan. Walaupun dalam beberapa surat kabar di Jawa Timur banyak yang memberitakan kemajuan industri dan minimnya pengangguran di Sidoarjo pada masa Orde Baru. Hal ini terkait politik informasi pada periode itu (Ridho'i, 2017b: 68).

Informasi tentang pengangguran di surat kabar bertolak belakang dengan data statistik yang dilaporkan BPS tentang peningkatan angka pengangguran di Sidoarjo tahun 19791982 berikut.

\begin{tabular}{|c|c|}
\hline Tahun & $\begin{array}{c}\text { Angka } \\
\text { Pengangguran }\end{array}$ \\
\hline 1979 & 1.321 \\
\hline 1980 & 2.515 \\
\hline 1981 & 2.676 \\
\hline 1982 & 3.131 \\
\hline
\end{tabular}

Tabel 1. Angka pengangguran di Sidoarjo. Sumber: BPS, 1983: 47.

Data BPS tersebut bertolak belakang dengan informasi Kompas 14 Mei 1974, sebagaimana dikutip Ridho'i (2017b) yang menyatakan bahwa Sidoarjo adalah daerah bebas pengangguran. Politik informasi pada masa Orde Baru pun terlihat pada judul keterangan tentang angka 'pengangguran' di laporan BPS yang dinamakan jumlah 'orang yang belum bekerja' (BPS, 1983: 47). Kenyataan tentang pengangguran menunjukkan bahwa pembangunan industri besar tidak hanya memunculkan lapangan pekerjaan tetapi juga mengakibatkan tersisihnya para pekerja nonprofesional (non-skilled labour). Fenomena yang muncul akibat beralihnya lahan kerja para petani dan pekerja perkebunan menjadi lokasi industri umumnya diikuti oleh kondisi kemiskinan mereka yang kehilangan lapangan pekerjaan (Hafidz dalam Ridho'i, 2017: 68).

Menanggapi permasalahan tersebut, seharusnya pengembangan wilayah Gerbangkertosusila dilakukan dengan membagi wilayah-wilayah ke dalam kelompok fungsi tertentu yang bersifat komplementer (saling melengkapi). Pembagian fungsi 
wilayah tersebut disesuaikan dengan potensi dan permasalahan di masingmasing kabupaten/kota. Harus ada pembagian fungsi kota perdagangan/ jasa, fungsi produksi primer (pertanian, peternakan, perikanan dan tambak), serta fungsi produksi sekunder (industri pengolahan).

Dengan adanya fungsi-fungsi wilayah yang komplementer tersebut, maka akan terjalin keterkaitan antarwilayah dan dapat memecah dominasi Kota Surabaya. Oleh karena itu, peluang bagi wilayah-wilayah lainnya untuk sama-sama berkembang, khususnya di Sidoarjo dapat dibuka. Jika hal itu tidak dapat dilakukan, maka kebijakan pemerintah tidak ada bedanya dengan eksploitasi lahan. Sidoarjo sebagai kota delta yang subur justru difungsikan sebagai kota industri. Seharusnya kawasan tersebut dijadikan sebagai penghasil komoditas pertanian, perikanan, dan kerajinan rakyat.

Keadaan semakin eksploitatif ketika pada awal abad ke-21 pemerintah kabupaten mencanangkan tiga zona industri yang dikenal dengan nama Siborian (Jabon-Krian). Menurut Kristanto (2005: 46), penggunaan lahan industri di kawasan Siborian mencakup tanah-tanah strategis di pinggir jalan raya dan daerah aliran sungai. Tujuan utama menggunakan lahan pada lokasi tersebut yaitu agar mempermudah transfer produk industri. Selain itu, mempermudah pembuangan limbah industri ke sungai.

Jelas terlihat bahwa pengembangan wilayah Gerbangkertosusila membawa dampak yang buruk bagi wilayah periurban Sidoarjo, khususnya bagi lingkungannya. Ternyata kebijakan tersebut belum bisa memeratakan wilayah, melainkan hanya mengeksploitasi wilayah Sidoarjo karena Kota Surabaya yang notabene sudah kehabisan lahan untuk pembangunan. Kebijakan tersebut justru bermuara pada kesenjangan antara wilayah urban dan peri-urban. Banyak lahan yang dieksploitasi oleh pemerintah dan swasta untuk dijadikan industri manufaktur dan perumahan. Sampai tahun 2011, belum ada pengaturan dan pembagian fungsi wilayah berdasarkan kondisi ekologis dari wilayah tersebut. Harus ada jalan tengah untuk mengatasi permasalahan ini agar masyarakat di wilayah Gerbangkertosusila, khususnya Sidoarjo bisa mendapatkan kesejahteraan. Tidak hanya masyarakat, penggunaan lahan untuk industrialisasi di Sidoarjo juga harus diperhatikan agar tidak terjadi degradasi lingkungan yang berlebihan.

Eksploitasi lahan di Sidoarjo tidak hanya dalam bentuk industri manufaktur. Tahun 1996/1997 telah dilakukan eksplorasi sumber daya alam berupa gas yang ada di Kecamatan Porong, Sidoarjo. Perusahaan yang bertanggung jawab dalam eksplorasi gas tersebut adalah PT. Lapindo Brantas Inc. Dalam proses pembebasan lahan tahun 1996 warga setempat diresahkan karena eksploitasi terhadap migas tersebut disamarkan menjadi peternakan ayam. Hal ini dilakukan agar pembebasan lahan berlangsung lancar 
Handep, Vol. 2, No. 1, Desember 2018

tanpa adanya demonstrasi dari warga. PT Lapindo Brantas Inc. sudah memulai eksploitasi migas sejak tahun 1997 (Santoso, 2010: 166-167). Kegiatan tersebut terus menerus dilakukan sampai tahun 2006, ketika terjadi semburan lumpur panas akibat pergeseran lempeng bumi sehari setelah gempa di Jogja.

Peristiwa semburan lumpur Lapindo menjadi pelajaran terhadap pemerintah setempat. Semburan yang sampai saat ini masih terjadi dan permasalahan ganti rugi yang hingga kini tidak ujung tuntas membuat hal ini menjadi fenomena bencana nasional. Walaupun demikian, eksploitasi lahan untuk industri manufaktur masih tetap dilakukan dan berpindah di kawasan selain di Porong. Pada tahun 2010/2011 kegiatan perindustrian sudah mulai berpindah ke arah Sidoarjo bagian Barat, yakni daerah Krian.

\section{Sidoarjo, Nasibmu Kini}

Purnawan Basundoro (2001: 133) menjelaskan bahwa industrialisasi berdampak pada kehidupan manusia dan juga lingkungan sekitarnya. Hal itu dapat mengakibatkan perubahan sosial dan fisik di perkotaan. Perubahan fisik antara lain perubahan fisik kota dan pencemaran lingkungan. Perubahan tersebut secara tidak langsung menimbulkan permasalahan ekologi kota. Pada kasus ini, penggunaan lahan untuk industri di Sidoarjo mulai mengalami peningkatan. Ini dipicu oleh berkembangnya zona industri Siborian di awal abad ke-21. Saat ini lahan-lahan strategis di pinggir jalan dan daerah aliran sungai sudah mulai dibangun pabrik-pabrik dan pergudangan. Sawahsawah mulai dibangun perumahan dan harga tanah sudah mulai melonjak akibat industrialisasi dan pemekaran wilayah.

Industrialisasi di Sidoarjo juga sudah mulai memperlihatkan dampaknya. Berdasarkan laporan dari Badan Lingkungan Hidup tahun 2002, industrialisasi lebih banyak berdampak negatif bagi lingkungan dan manusia. Hal tersebut disebabkan oleh polusi yang dihasilkannya, antara lain polusi air dan udara.

Industri manufaktur memberikan kontribusi besar terhadap polusi air, yakni sekitar $61,25 \%$. Sedangkan sisanya ditimbulkan dari limbah rumah tangga sebesar $27,48 \%$ dan agro industri sebesar $11,27 \%$. Ini merupakan bukti nyata bahwa sungai-sungai di Delta Brantas sudah mulai tercemar. Permasalahan ini bukan merupakan permasalahan yang ringan, karena tingkat pencemaran sudah melebihi $50 \%$. Beberapa hal tersebut bukan satusatunya permasalahan, karena masih ada polusi udara, dan permasalahan lingkungan sosio-kultural (Kompas, 19 Maret 2008).

Polusi air dalam berita terbaru tanggal 13 Juni 2015 yang dimuat Madiun Pos berakibat pada kemunculan fenomena buara muara yang pindah ke barat menuju kali Porong (lihat gambar 5). Perpindahan buaya muara tersebut disebabkan tercemarnya habitat mereka oleh semburan lumpur lapindo yang 
mengotori Kali Porong yang terletak tepat di sebelah selatan lokasi semburan. Air yang disemburkan bersama dengan lumpur tersebut dialirkan ke Kali Porong. Setelah hampir sepuluh tahun, muncullah lumpur seperti pulau baru di muara sungai. Kondisi air di sungai dan muaranya saat ini mulai tercemar (Madiun Pos, 13 Juni 2015).

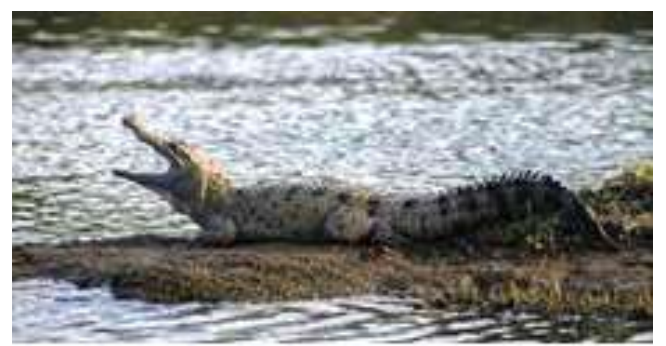

Gambar 5. Fenomena munculnya buaya di Kali Porong.

Sumber: http://www.jatengpos.com/2015/06/ buaya-sidoarjo-rencana-bksda-tangkapbuaya-ditentang-warga-mengapa-613954, diakses pada Juni 2018.

Selain polusi air, juga ada polusi udara. Berdasarkan laporan dari Balai Penelitian Gangguan Akibat Kekurangan Yodium (BP GAKY) tahun 2006, terdapat belasan pasien di Sidoarjo yang terkena penyakit kretinisme dan gondok. Penyakit tersebut disebabkan oleh polusi udara yang berasal dari karbondioksida berlebih yang dihasilkan oleh industri manufaktur, bahkan juga pencemaran limbah industri dan limbah rumah tangga yang ada di sekitar mereka (Kompas, 19 Maret 2008).

Permasalahan lingkungan sosiokultural yang belakangan muncul adalah akibat eksploitasi lahan di Sidoarjo yaitu semburan Lumpur
Lapindo. Peristiwa yang terjadi pada tanggal 29 Mei 2006 tersebut menenggelamkan empat desa di sekitar PT Lapindo Brantas Inc. Banyak warga yang kehilangan tempat tinggal karena peristiwa tersebut (Rifai, 2009: xvii). Perusahaan yang dimiliki Bakrie ini memberikan ganti rugi kepada warga, tetapi kenyataannya warga tidak mendapatkan ganti rugi sepenuhnya. Hampir sepuluh tahun ini semburan lumpur tersebut masih belum berhenti, walaupun saat ini volume semburannya telah berkurang. Semburan Lumpur Lapindo ini merupakan dampak dari eksploitasi lahan industri migas yang kemudian menjadi bencana nasional (Madiun Pos, 13 Juni 2015). Fenomena ini sangat wajar mengingat dampak yang muncul dari industri migas tersebut memang selalu menimbulkan degradasi lingkungan.

\section{PENUTUP}

SWP Gerbangkertosusila merupakan merupakan program yang cenderung eksploitatif terhadap wilayah-wilayah di sekitar Surabaya, khususnya Sidoarjo. Hal itu ditunjukkan oleh ekspansi industri dan penggunaan lahan untuk permukiman. Semenjak Perda tentang Gerbangkertosusila diberlakukan maka penggunaan lahan untuk industri, permukiman, dan kegiatan perekonomian lainnya mulai meningkat. Lahan untuk pertanian, perkebunan, pertambakan, dan ruang terbuka hijau lainnya sudah mulai berkurang. 
Handep, Vol. 2, No. 1, Desember 2018

Sidoarjo yang merupakan kawasan peri-urban kini menjadi kawasan urban yang sibuk dengan industrialisasinya. Banyak pendatang yang notabene adalah buruh pabrik memilih mencari pekerjaan di Sidoarjo dibandingkan di Surabaya. Pertambahan penduduk di kawasan ini tumbuh lebih cepat dibanding kawasan lain yang termasuk Gerbangkertosusila. Penggunaan lahan untuk industri juga semakin banyak karena infrastruktur jalan sudah semakin baik. Kondisi nyata tentang penggunaan lahan tersebut yaitu dengan adanya zona industri Siborian (Sidoarjo Jabon Krian). Penggunaan lahan untuk industrialisasi pada dasarnya merupakan eksploitasi yang dilakukan oleh negara dan swasta untuk meningkatkan perekonomian mereka.

Jika dilihat dampaknya, SWP Gerbangkertosusila juga menghasilkan dampak buruk terhadap lingkungan dan kesehatan. Dari kajian ini seharusnya masa lalu yang buruk dari industrialisasi di Sidoarjo menjadi lonceng pengingat agar setiap wilayah di negeri ini tidak hanya dieksploitasi, tapi juga benarbenar harus dikembangkan dengan bijaksana.

\section{DAFTAR SUMBER}

Adika, I.N. 2003. Perkembangan Wilayah Pinggiran Kota Metropolitan Surabaya dan Mobilitas Tenaga Kerja (Kasus Kabupaten Sidoarjo).Disertasi. Yogyakarta: UGM.

ANRI, Arsip Karesidenan Surabaya No.Inv. 560 Tahun 1910.
Arsip Badan Lingkungan Hidup (BLH) Sidoarjo, 2002.

Badan Pusat Statistik (BPS), Sidoarjo Dalam Angka 2003, 2004. 2010. Sidoarjo Dalam Angka 2009, , Sidoarjo Dalam Angka 2011, 2012.

Basundoro, P. 2001. Industrialisasi, Perkembangan Kota, dan Respon Masyarakat (Studi Kasus Kota Gresik). Humaniora, Volume XIII, No. 2, hlm. 133-140.

, 2012. Pengantar Sejarah Kota. Yogyakarta: Ombak.

colonialarchitecture.eu, diakses pada Juli 2018 .

Couch, C (et al). 2007. Urban Sprawl in Europe: Landscapes, Land-Use Change \& Policy. London: Blackwell Publishing.

Dick, H.W (eds.). 1997. Balanced Development: East Java in the New Order, Pembangunan yang Berimbang: Jawa Timur dalam Era Orde Baru. Jakarta: Gramedia. 2002. Surabaya City of Work: A Socio-economic History, 1900 2000. Athens: Ohio University Press.

Forman, R.T.T. 2008. Urban Regions: Ecology and Planning Beyond the City. New York: Cambridge University Press. 
Freire, M.E. \& Stren, R. 2001. The Challange of Urban Government: Policies and Practice. Washington: The World Bank Institute.

Handayani, F.A. 2009. Analisis Kesenjangan Wilayah di Gerbangkertosusila Ditinjau dari Aspek Ekonomi, Sosial dan Lingkungan. Tugas Akhir. Surabaya: Institut Teknologi Surabaya.

Hoggart, K. 2005. The City's Hinterland : Dynamism and Divergence in Europe's Peri-Urban Territories (Perspectives On Rural Policy And Planning). London: ASHGATE.

https://upload.wikimedia.org/ wikipedia/commons/1/19/ East Java province.png, diakses pada Desember 2018.

http://www.jatengpos.com/2015/06/ buaya-siduarjo-rencana-bksdatangkap-buaya-ditentang-wargamengapa-613954, diakses pada Juni 2018.

Kompas, 1 September 2004. Menerima Limpahan Akibat Keterbatasan Lahan.

Kompas, 19 Maret 2008. Polusi Udara Bisa Sebabkan Kekurangan Yodium.

Kristanto, C. 2005. The Practice of Environmental Management in Industrial Zone (Case Study: Industrial Zone of Krian By Pass Sidoarjo-Indonesia). Tesis.
Yogyakarta: Universitas Gadjah Mada.

Kuntowijoyo. 2003. Metodologi Sejarah. Yogyakarta: Tiara Wacana.

Laporan Dinas Penanaman Modal Jatim, 2001.

Madiun Pos, 13 Juni 2015.

Perda Jatim No.4/1996 tentang RTRW Provinsi Jawa Timur, 1996.

PP No.47/1996 tentang RTRW Nasional, 1996.

Rencana BKSDA Tangkap Buaya Ditentang Warga, Mengapa? 13 Juni 2015, diunduh dari http:// $\mathrm{madiun}$.solopos.com/read/ 20150613/516/613954/buayasidoarjo-rencana-bksda-tangkapbuaya-ditentang-warga-mengapa?, pada 16 Juni 2015.

Ridho'i, R. 2017a. “Doom to Disaster? Industrial Pollution in Sidoarjo 1975-2006". Lembaran Sejarah, Vol. 13, No. 2, Oktober 2017, hlm. 204-220.

2017b. Di Balik yang Tersurat: Kontroversi Arsip Industrialisasi dan Polusi di Sidoarjo 1970-2000an. Diplomatika, Vol. 1, No. 1, September 2017, hlm. 61-70.

Rifai, R. 2009. Spatial Modeling and Elements at Risk Assessment of Sidoarjo Mud Volcanic Flow. Tesis. Yogyakarta: Graduate School Gadjah Mada University. 
Handep, Vol. 2, No. 1, Desember 2018

Santoso, E.B. 2010. Strategi Pengembangan Perkotaan di Wilayah Gerbangkertosusila Berdasarkan Pendekatan Daya Saing Wilayah. Makalah Pada Seminar Nasional Perencanaan Wilayah dan Kota ITS (Inovasi Dalam Riset dan Praktek Perencanaan Menuju Penataan Ruang Kota Masa Depan). Surabaya: ITS.

Santoso, V. 2010. Lapindo - Jer Basuki (ku) Mawa Bea (mu)" Java Collapse: dari Kerja Paksa Hingga Lumpur Lapindo. Yogyakarta: Insist Press.

Sekretariat Jenderal Kementerian Pekerjaan Umum. 2013. Peta Struktur dan Pola Ruang KSN Gerbangkertosusila, diunduh dari https://slideplayer.info/slide/ 11857144/, pada Juli 2018.

Tim Penulis. 2001. The List of Domestic and Foreign Investment Companies in East Java Year 2000. Surabaya: East Java Regional Investment Coordinating Board.

Tjiptoatmodjo, F.A.S. 1983. Kota-kota Pantai di Sekitar Selat Madura (Abad XVII Sampai Medio Abad XIX. Disertasi. Yogyakarta: Jurusan Sejarah FIB UGM.

Wood, E.M. 2002. The Origin of Capitalism. London: Verso.

Yunus, H.S. 2008. Dinamika Wilayah Peri-Urban: Determinan Masa
Depan Kota. Yogyakarta: Pustaka Pelajar. 2014. Klasifikasi Kota. Yogyakarta: Pustaka Pelajar. 